\title{
Corrigendum
}

\section{Forging empire: Angkorian iron smelting, community and ritual practice at Tonle Bak-CORRIGENDUM}

Mitch Hendrickson, Stéphanie Leroy, Cristina Castillo, Quan Hua, Enrique Vega \& Kaseka Phon

Published by Cambridge University Press, 10 December 2019

This article presented the results of archaeobotanical analysis identifying lotus (Nelumbo nucifera) seeds at Tonle Bak. Due to the questionable size difference compared with modern botanical samples, co-author Cristina Castillo has subsequently re-examined the seeds. Upon dissection and consideration of their internal structure, a sample of these seeds have been found to be black pepper (Piper nigrum). Hence, although lotus plants are attested in the Tonle Bak area through texts, inscriptions, iconography and pollen evidence, they are not yet unequivocally documented by macro plant remains.

\section{Full reference}

Hendrickson, M., S. Leroy, C. Castillo, Q. Hua, E. Vega \& K. Phon. 2019. Forging empire: Angkorian iron smelting, community and ritual practice at Tonle Bak. Antiquity 93: 1586-606. https://oi.org/10.15184/aqy.2019.174 